\title{
First Sighting of IUCN red listed Three Bird species of Family : Accipitridae at Todgarh Raoli Wildlife Sanctuary, Rajasthan, India
}

\author{
${ }^{1}$ C. S. Purohit, ${ }^{* 2}$ Mohan Singh, ${ }^{3}$ Partap Singh, ${ }^{4}$ Abhinav Bharti \\ ${ }^{1}$ Botanical Survey of India, Andaman \& Nicobar Regional Centre, Port Blair, India \\ ${ }^{* 2}$ Department of Zoology, Jai Narain Vyas University, Jodhpur, Rajasthan, India \\ ${ }^{3}$ Department of Zoology, Govt. Dungar PG College, Bikaner, Rajasthan, India \\ ${ }^{4}$ Raoli Range, Todgarh-Raoli wls, Rajasthan Forest Department, Rajasthan, India \\ *corresponding author's email: mssolanki12298@gmail.com
}

\begin{abstract}
This paper deals with addition of three raptor birds species (Family: Accipitridae) from Todgarh-Raoli wildlife sanctuary; in which two species i.e. Crested serpent eagle and Crested Hawk eagle are addition to avian diversity of Rajasthan desert and one bird species (Short toed eagle) is first record from this sanctuary. Taxonomic description, distribution, vernacular name, present status, location map and photographs are provide here for their easy identification and updating of avian diversity of Todgarh-Raoli wildlife sanctuary.
\end{abstract}

Keywords : Avifauna Addition, Raptors, Rajasthan Desert, Todgarh-Raoli Wls.

\section{INTRODUCTION}

As India is one of the 12 Megabiodiversity countries, it supports a considerable amount of avifaunal population. There are approximately 233 species of raptors recorded throughout the world (Howard and Moore, 2003), out of which Indian subcontinent supports 82 species of them (Ali \& Ripley, 1983; Debnath, et. al., 2018). Rajasthan, the largest state of India in terms of area, is located on its western side, also contributes 46 raptor species (Birdlife international website). Of these, 7 species (Elanus caeruleus, Milvus migrans, Neophron percnopterus, Gyps bengalensis, Gyps indicus, Accipiter badius, Butastur teesa) of the birds of prey (Family: Accipitridae) have been reported from Todgarh Raoli wildlife sanctuary (Koli, 2014). Numerous ornithological studies on diversity have been carried out in Rajasthan. However, protected areas have been less explored with regard to avian diversity. The present study is to explore the diversity of unsighted birds of prey (Family: Accipitridae) of the TodgarhRaoli wildlife sanctuary.

\section{Study Area}

This Sanctuary is situated between $73^{\circ} 40^{\prime}$ to $74^{\circ} 10^{\prime}$ east longitudes and $25^{\circ} 20^{\prime}$ to $26^{\circ} 0^{\prime}$ north latitudes, just $110 \mathrm{~km}$ in the southwest of famous city "Ajmer" which bears most fragile montane ecosystem of Aravallis. It covers an area of about $495.27 \mathrm{~km}^{2}$ and extends in three revenue districts viz., Rajsamand, Pali and Ajmer in the south-western part of Rajasthan State. It is one of the protected areas expressing full range of habitat of Aravalli ecosystem which has exceptionally rich biodiversity. Rich diversity in the area is due to interspersion of habitats which includes areas of Dhok, Salar, dryland, seasonal streams, cascading mountains and newly formed sand dunes, formed on western hill aspects and fine grooves of mixed wood lands. These habitats provide shelter to 
wide range of fauna. It is significant biogeographically also, as the sanctuary makes an ecotone between hilly forests of Aravallis and Thar Desert situated in the north-west. The hills of this sanctuary act like a barrier, checking eastward extension of desert. The sanctuary has number of historical and religious places like Todgarh, Mangadji ka Mahal, Dudhaleshwar Mahadev, Dhareshwar Mahadeo, Goramji ka Mandir, Vayad Bheruji ka Mandir, Kajalwas Dhuni etc. These sacred places are playing a vital role in conservation of the biodiversity of the sanctuary.

Run off of Todgarh catchment is drained out by several 'nallahs' which ultimately form tributaries to drain in Dholapani, Sukdi, Jogmandi, Digore, Siryari, Rania rivers. Nine dams viz., Phulad, Gajnal, Rodawas, Jogmandi, Hansiyawas, Hichliawas, Digore, Siryari, Rania have been constructed on these rivers, originating from Todgarh hills.

\section{MATERIAL AND METHODS}

The present study was an aim of documentation of diversity of birds from Todgarh-Raoli wildlife sanctuary. During the survey of sanctuary from year 2015 to year 2019, we have sighted 8 different bird species of family Accipitridae. All the bird species have been identified by using various published literature and field guides (Ali \& Ripley, 1986; Beaman \& Medge 1998; Grimmet et al., 1999). After critical examination we could identify three new additions to the checklist of raptors for this sanctuary. The new species were later confirmed by raptor specialists of India.

\section{III.RESULTS AND DISCUSSION}

Out of 8 raptor species observed during our survey, three species are first time record from this sanctuary and are addition to bird diversity of Todgarh-Raoli wildlife sanctuary. Interestingly, two species (Crested hawk eagle and Crested serpent eagle) are first records for the Thar Desert. Current nomenclature citation, taxonomic description, distribution, along with vernacular name, and status of each bird species are provided below in alphabetical order.

\section{(1) SHORT-TOED SNAKE EAGLE, Circaetus gallicus} (Gmelin, 1771)

Taxonomic description: The short toed eagle is a medium sized raptor with a widespread distribution throughout Europe, North Africa and parts of Asia that hunts mainly reptiles in open areas. It builds nest mainly in trees and raise only one young per year (Hadad et. al., 2015). Adult is large, pale, long winged raptor. Plumage pattern combined with broad middle of wing and often rather rounded looking wing tips give impression of huge pale buzzard rather than classic eagle (Beaman and Madge, 1998). The bird is earthy brown above and chin, throat and upper breast are earthy brown (Plate 1). The tail has three or four dark bands and the terminal one is broadest. The wings reach almost till the end of tail and long tarsus is unfeathered. No obvious sexual dimorphism exists, except in the comparative body size of the sexes; male being only slightly smaller than female [Fig.-1].

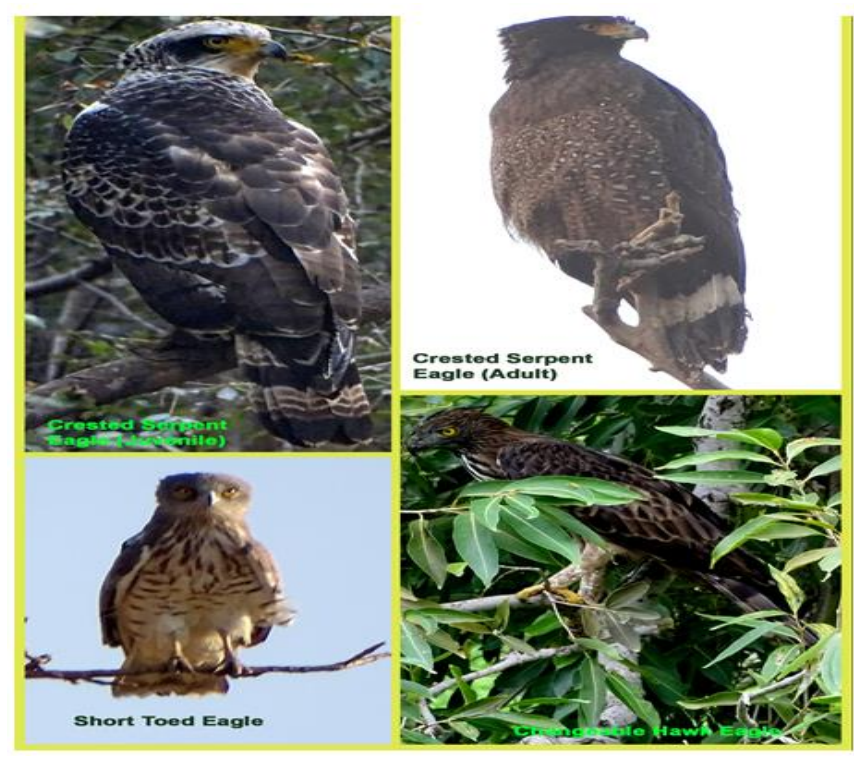

Fig. 1 Reptors 
Distribution: The species is well distributed in Pakistan, South Nepal throughout India in Indian subcontinent except Bangladesh and Assam. In Rajasthan the species has been recorded from Jhalawar, Churu, Jhunjhunu, Bharatpur, Bikaner and Jodhpur. According to Vyas (2013) it occurs throughout Rajasthan except drier parts of the desert.

Vernacular name: Sampmaar

Status: According to Birdlife International (2016) the species belong to Least Concerned category of IUCN red list.

Location with GPS: In Todgarh-Raoli wildlife sanctuary, the species was sighted at Jojawar Range, Solankia-Garh, 26.Nov.2017, 25³0'9.617"N, 7346'43.176'"E, 417m [Fig.-2].

\section{(2) CRESTED HAWK EAGLE, Nisaetus cirrhatus} (Gmelin, 1788).

Taxonomic description: It is a medium sized raptor with a body length of $58-77 \mathrm{~cm}$. Its wings are broad and tail too is long and broad. A prominent whitetipped black crest sticks out from the hind crown. The long tail is the same colour as the upperparts. There is a wide dark subterminal bar, followed by 3-4 narrower dark brown bars towards the base. The breast and belly are white with bold dark brown streaks (Plate 1). The long and powerful feathered legs, as well as the undertail coverts, are buff with fine white bars. The crested hawk eagle glides on bowed wings when the bars on the primaries can often be seen. Frequently, gliding alternates with 3-4 powerful beats of the fully extended wings [Fig.-1].

Distribution: The species is quite common in forested areas in peninsular India to Sri Lanka. The species in Rajasthan occurs in east and Southern parts. The species is the first record from the arid region of Rajasthan.

Vernacular name: Shah Baaz and Mor Baaz.

Status: According to Birdlife International (2013) the species belong to Least Concerned category of IUCN red list.
Note: This bird is uncommon and only reported from South and Eastern Rajasthan. This is the first sighting from Satpalia forest in Semi Arid Zone of Rajasthan.

Location with GPS: In Todgarh-Raoli wildlife sanctuary, the species was observed in Bhim Range, Satpalia forest on $10^{\text {th }}$ Nov. 2018, $25^{\circ} 25^{\prime} 25.157^{\prime \prime} \mathrm{N}$,

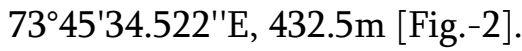

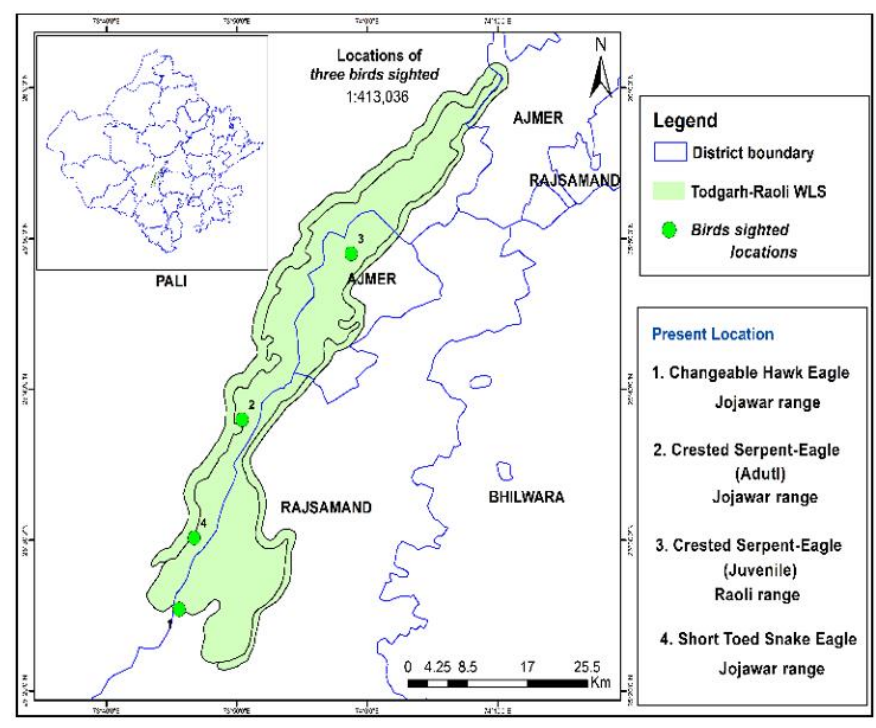

Fig. 2. Location map of Raptors

\section{(3) CRESTED SERPENT EAGLE, Spilornis cheela} (Latham, 1790)

Taxonomic description: This species is a medium sized raptor of $56-74 \mathrm{~cm}$ length with broad and rounded wings. It soars with wings held forward in a pronounced "V" shape. It has black and white crest, yellow cere, lores and legs, which are largely unfeathered. Adult has broad white bands across wings and tail and white spotting and barring on brown underparts. Juvenile has blackish ear coverts, whitish head and underparts, and has narrower barring on tail than adult. The underwings are white with fine dark barring and dark trailing edge [Fig.-1].

Distribution: The species is well distributed in Northeast and North-west of Indian subcontinent. In Rajasthan it has been reported from East, South and South-eastern parts of the state.

Vernacular name: Baj, Cheel. 
Status: According to Birdlife International (2016a) the species belong to Least Concerned category of IUCN red list.

Note: This bird species in reported from Eastern and Southern Rajasthan. This is the first report of the species from Rajasthan desert.

Location with GPS: Adult: In Todgarh-Raoli wildlife sanctuary it was observed in Jojawar Range, Kajalwas on 25th Nov. 2018, 25³7'59.764"N, 7350'23.837'E, $394.1 \mathrm{~m}$ (see location map, Plate 2). Juvenile: In Todgarh-Raoli wildlife sanctuary a juvenile was sighted in Raoli Range, Thoria-deh on $17^{\text {th }}$ Nov. 2017, $25^{\circ} 48^{\prime} 59.864^{\prime \prime} \mathrm{N}, 73^{\circ} 58^{\prime} 45.706 " \mathrm{E}, 495.7 \mathrm{~m}$ [Fig.-2].

\section{IV.CONCLUSION}

During the survey of Todgarh-Raoli wildlife sanctuary, we have sighted three new bird species which are addition to the Avian diversity of this sanctuary. Among these, two species (Crested serpent eagle and Crested Hawk eagle) are first records from Rajasthan desert. Though one bird species (Short toed eagle) is previously reported from Rajasthan desert but is first record from this sanctuary.

\section{ACKNOWLEDGEMENTS}

The author is thankful to Director, Botanical Survey of India, Kolkatta and HOO, BSI, AZRC, Jodhpur for providing necessary facilities. Thanks also extend to Forest Department, Todgarh-Raoli WLS for giving permission to facilitate survey of protected areas. We are also very thankful to Mr. Nirav Bhatt, a raptor specialist, for confirming the IDs of these birds.

\section{REFERENCES}

[1]. Ali S. and S.D. Ripley 1986. Handbook of the bird of India and Pakistan (Vol. 5- Lark to Grey Hypocolius). Oxford University Press.
[2]. Beaman M. and S. Madge 1998. The Handbook of bird identification for Europe and the Western Palearctic. Christopher helm. A and C Black. London.

[3]. Bharos A.M.K. and F. Bux 2018. Avifauna of Kalidarha dam and Shishupal cliff in Mahasamund district, Chhattisgarh, India. Asian journal of conservation biology. 7(2): 119124.

[4]. Bird Life International 2013. Nisaetus cirrhatus. The IUCN Red List of Threatened Species 2013: e.T22732090A50443847. https://dx.doi.org/10.2305/IUCN.UK.20132.RLTS.T22732090A50443847.en. Downloaded on 30 March 2020.

[5]. Bird Life International 2016. Circaetus gallicus. The IUCN Red List of Threatened Species 2016: e.T22734216A95078150. https://dx.doi.org/10.2305/IUCN.UK.20163.RLTS.T22734216A95078150.en. Downloaded on 30 March 2020.

[6]. Bird Life International 2016a. Spilornis cheela. The IUCN Red List of Threatened Species 2016: e.T22695293A95221642. https://dx.doi.org/10.2305/IUCN.UK.20163.RLTS.T22695293A95221642.en. Downloaded on 30 March 2020.

[7]. Chhangani A.K. 2002. Avifauna of Kumbhalgarh wildlife sanctuary in the aravali hills of Rajasthan. Zoo's print journal. 17(4):764-768.

[8]. Debnath S., S. Biswas and A.K. Panigrahi 2018. Present status and diversity of avian fauna in Purbasthali bird sanctuary, West Bengal, India. Agric. Sci. Digest. 38(2): 35-102.

[9]. Dombrovski V.C. and V.V. Inanovaski 2005. New data on numbers and distribution of birds of prey breeding in Belarus. Acta Zoologica Lituanica. 15(3): 218-227.

[10]. Gamauf A., M. Preleuthner and W. Pinsker 1998. Distribution and field identification of 
Philippine birds of prey: 1. Philippine Hawk eagle (Spizaetus philippensis) and Changeable hawk eagle (Spizaetus -cirrhatus). Forktail 14(1998): 1-11.

[11]. Gjershaug J.O. 2006. Taxonomy and conservation status of Hawk eagles (GenusNisaetus) in South East Asia. PhD thesis. Norwegian university of science and technology Trondheim, Norway.

[12]. Gokula V. 2012. Breeding ecology of the Crested serpent eagle Spilornis cheela (Latham,1790) (Aves: Accipitriformes: Accipitridae) in Kolli hills, Tamil nadu, India. Tapromanica. 4(2): 77-82.

[13]. Grimmett R., C. Inskipp and T. Inskipp 1999. Pocket guide to the birds of the Indian subcontinent. Oxford university press. Pp 120121.

[14]. Hadad E., G. Weil and M. Charter 2015. The importance of natural habitats as Short toed eagle (Circaetus gallicus) breeding site. Avian biology research 8(3): 160-166.

[15]. Koli V.K. 2014. Diversity and status of avifauna in Todgarh Raoli wildlife sanctuary, Rajasthan, India. Journal of asia pacific biodiversity. 7: 401407.

[16]. Kumar A., R.P. Chaube and A. Kanaujia 2018. New records of birds from the Shahid Chandra Shekhar Azad bird sanctuary of Unnao, Uttar Pradesh, India. Journal of wildlife research. April-June, 6: 17-23.

[17]. Mori D., R. Vyas and K. Upadhyay 2017. Breeding biology of the Short toed snake eagle Circaetus gallicus. Indian birds. 12(6): 149-156.

[18]. Nijman V. 2006. The endemic Bawean serpent eagle Spilornis baweanus: habitat use, abundance and conservation. Bird conservation international (2006) 16: 131-143. Birdlife international 2006.

[19]. Rai D., G. Chopra, R. Gulia and P. Vats 2017. Avian diversity of Basai wetlands, Haryana
(India): An IBA site. J. Exp. Zool. India, 20(1): 109-117.

[20]. Senanayake U., P. Ratnayake, S. Siriwardena and D. Pathirge 2017. Changeable hawk eagle Nisaetus cirrhatus ceylanensis nesting in association with Giant honey bees Apis dorsata. Birding ASIA 27: 54-56.

[21]. Shekhawat D.S. and C. Bhatnagar 2014. Guild, status and diversity of avian fauna in the Jhunjhunu district, Rajasthan, India. Journal of asia pacific biodiversity 30: 1-6.

[22]. Vyas, R. 2013. Birds of Rajasthan. BNHS \& Oxford University Press, New Delhi. Pp xiv + 326.

Cite this article as : C. S. Purohit, Mohan Singh, Partap Singh, Abhinav Bharti, "First Sighting of IUCN red listed Three Bird species of Family : Accipitridae at Todgarh Raoli Wildlife Sanctuary, Rajasthan, India", International Journal of Scientific Research in Science and Technology (IJSRST), Online ISSN : 2395-602X, Print ISSN : 2395-6011, Volume 7 Issue 2, pp. 366-370, March-April 2020. Available at doi : https://doi.org/10.32628/IJSRST207264 Journal URL : http://ijsrst.com/IJSRST207264 